\title{
Spatio-temporal trends in the predation of large gulls by peregrine falcons (Falco peregrinus) in an insular breeding population
}

\author{
Časopriestorové trendy predácie vel'kých čajok sokolmi st’ahovavými (Falco peregrinus) \\ v ostrovnej hniezdnej populácii
}

\author{
Luke J. SUTTON, Ryan A. BURRELL \& Seb LORAM
}

\begin{abstract}
Individual diet specialization occurs in many populations of generalist predators, with specific individuals developing specialist strategies in their feeding behaviour. Intraspecific resource partitioning is hypothesised to be common amongst species in higher trophic levels where competition for resources is intense, and a key driver in breeding success and community structure. Though well-studied in other predators, there is sparse data on ecological specialization in raptors, which are important drivers of community and trophic structure. In this study, the breeding season diet of an insular population of peregrine falcons (Falco peregrinus) was determined from indirect analysis of prey remains collected over three years. An unexpected result was the high proportion of large gulls (Laridae), of the genus Larus, in the diet of two breeding pairs of peregrines. Large gulls made up $18.44 \%$ by frequency of total prey recorded and $30.81 \%$ by biomass. Herring gulls (Larus argentatus) were the most common large gull prey, with immatures most frequent $(67.95 \%)$ compared to adults $(19.23 \%)$. Overall, most gulls predated were immatures $(80.77 \%)$. Frequency of predation varied between breeding pairs and months, but was consistent over the three years. Most gulls were taken in April (37.17\%), followed by May (19.23\%), with a smaller peak of immature herring gulls taken in August and September. The pattern of regular predation by peregrines on large gulls is a new observation with important implications for understanding individual diet specialization in raptors, and its effect on bird populations and community structure.
\end{abstract}

\begin{abstract}
Abstrakt: Individuálna potravná špecializácia sa vyskytuje v mnohých populáciách generalistických predátorov, kde si jedince vytvárajú špecializované stratégie v ich potravnom správaní. Predpokladá sa, že vnútrodruhové prerozdel’ovanie zdrojov je bežné pre druhy na vyšších trofických úrovniach, kde je intenzívna konkurencia o zdroje potravy a tak je hlavný faktor hniezdneho úspechu a štruktúry spoločenstva. Hoci je ekologická špecializácia dobre študovaná u iných predátorov, údajov o dravých vtákov, dôležitých činitelov ovplyvňujúcich trofickú štruktúru spoločenstva, je málo. Potrava sokola st’ahovavého (Falco peregrinus) $\mathrm{z}$ ostrovnej populácie počas hniezdnej sezóny sa v tejto štúdii určila nepriamou analýzou zvyškov koristi zbieraných počas troch rokov. Neočakávaným výsledkom bol vel'ký podiel vel'kých čajok (Laridae) z rodu Larus v potrave dvoch hniezdnych párov sokola. Frekvencia výskytu vel'kých čajok v koristi bola $18,44 \%$ a $30,81 \%$ jej celkovej biomasy. Najčastejšie lovenou vel'kou čajkou bola čajka striebristá (Larus argentatus), mladé jedince častejšie $(67,95 \%)$ než dospelé $(19,23 \%)$. Celkovo, najčastejšie boli predované mladé jedince $(80,77 \%$ ). Frekvencia predácie varírovala medzi hniezdiacimi pármi a mesiacmi, avšak bola zhodná počas troch rokov. Väčšina čajok bola ulovená $\mathrm{v}$ apríli $(37,17 \%)$ a v máji $(19,23 \%)$, s menším nárastom početnosti nedospelých jedincov čajky striebristej ulovených v auguste a septembri. Spôsob pravidelného predovania vel'kých čajok sokolmi je novým pozorovaním dôležitým pre pochopenie individuálnej potravnej špecializácie dravcov a na jej vplyv na vtáčie populácie a štruktúru spoločenstva.
\end{abstract}

Key words: diet, dietary breadth, individual diet specialization, large prey species

Luke J. Sutton (corresponding author), School of Biological and Marine Sciences, Plymouth University, Drake Circus, Plymouth, Devon, UK PL4 8AA, United Kingdom. E-mail: luke.sutton@students.plymouth.ac.uk.

Ryan A. Burrell, 10 West Mills Road, Fordingbridge, Hampshire, UK SP6 1GD, United Kingdom.

Seb Loram, Matemwe, Churston Road, Churston Ferrers, Devon UK TQ5 0HZ, United Kingdom.

Acknowledgments: Thanks to the Birds of Lundy Fund, Hawk and Owl Trust and Lundy Field Society for providing financial assistance for travel and accommodation expenses to L.J.S to enable fieldwork for this project. Thanks to Dean Jones (Warden) who provided support and advice, and Ed Drewitt who assisted with prey species identification. Tom Dickens and Ed Drewitt commented on earlier draft manuscripts and made useful suggestions.

\section{Introduction}

Ecological specialization is a key concept in ecology and evolutionary biology (Bolnick et al. 2003, Araujo et al. 2011), particularly individual diet specialization 
(IDS) with many populations of diet generalist species containing a number of specialized individuals (PaganiNunez et al. 2016). This resource partitioning is important in community and population ecology, where coexisting individuals within and amongst species differ in their use of limited resources to survive and reproduce (Schoener 1974, Wiens 1984). Individuals may reduce resource-use overlap and thus competition by utilising a narrower range of resources than conspecific competitors. Thus IDS is expected to be prevalent amongst species occupying higher trophic levels, such as raptors, where intraspecific competition for resources is high (Navarro-Lopez et al. 2014). Amongst the avifauna, IDS has been reported in many polar and temperate seabirds (Dehnhard et al. 2016, Horswill et al. 2016), possibly related to the predictability of food resources in the marine environment. However, recent studies of IDS within breeding populations of raptors are limited to a few species (e.g. Costantini et al. 2005, Whitfield et al. 2009, Navarro-Lopez et al. 2014, Terraube et al. 2014).

The peregrine falcon (Falco peregrinus) (hereafter 'peregrine') has one of the largest global ranges of any avian species, and is considered a diet generalist, mainly feeding on a wide range of other bird species (White et al. 2013). Most studies on peregrine feeding habits in the British Isles show a preference for a generalist diet (Ratcliffe 1993, Dixon 2005, Drewitt \& Dixon 2008), with most prey taken by breeding pairs in mainland coastal areas having a mean biomass $<500$ g (Sutton 2015a). The British Isles include many small offshore islands on their western seaboard, many of which have dense populations of breeding peregrines relative to their area. Mainland coastal breeding pairs in southern England may range between $2.10-5.30 \mathrm{~km}$ mean linear nearest neighbour distance, compared to 1.24-1.60 km for islands such as Lundy (Sutton 2016). Ratcliffe (1993) suggests that the distribution of these island breeding pairs is regulated by the local abundance of seabird communities, which are likely to constitute the main food source.

Density compensation theory predicts that island species tend towards a generalist strategy once released from competition with other species (Wright 1980). However, research from offshore island groups in British Columbia, Canada, show that the resident sub-species of peregrine F. p. pealei, has adapted to local prey availability and specialises in small seabirds, particularly the ancient murrelet (Synthliboramphus antiquus)
(Beebe 1960). However, the resident peregrine populations have been in decline over the past 30 years, most likely in response to declines in their seabird prey (Nelson 1990). Therefore, understanding IDS is important because of its potential to regulate population dynamics and influence breeding success in insular peregrine populations. Specialized individuals within raptor populations may have higher reproductive success than generalists (Zabala \& Zuberogoitia 2014), and breeding peregrines that have a higher proportion of large prey in the diet may have increased reproductive success in some areas (Dawson et al. 2011), though this observation is not consistent across all peregrine breeding populations (Zuberogoitia et al. 2013).

Lundy Island (hereafter 'Lundy') was formerly an important seabird station in the south west of the British Isles. Since the eradication of black (Rattus rattus) and brown rats ( $R$. norvegicus) in 2006, there has been an increase in numbers of breeding seabirds, particularly Manx shearwaters (Puffinus puffinus) (Booker \& Price 2014). This increase is predicted to continue with positive early signs of recovery in many of the seabird species breeding on the island (Brown et al. 2011). However, breeding pairs of two species of gull (Laridae), lesser black-backed gull (Larus fuscus) and herring gull (Larus argentatus), declined between 2000-2013 (from 443 to 242 and 762 to 428 breeding pairs respectively) (Price et al. 2014). Lundy also has a dense breeding population of peregrines, with five pairs resident between 2002-2015. Based on a total land area of 445 ha, this equates to one adult pair per $89 \mathrm{ha}$, and a mean linear distance between nest cliffs ranging between 1.24-1.60 km (Sutton 2016).

The factors influencing this high density are complex and not fully understood, however one contributory factor may be resource partitioning and IDS in the resident breeding pairs. As part of a long-term study on the feeding habits of the island peregrines, early diet analysis has demonstrated that Manx shearwaters are the principal prey for four of the breeding pairs (Sutton 2016). However, an unexpected finding was the regular predation of large gulls, particularly immature herring gulls (mean mass $=957 \mathrm{~g}$, BTO 2016) in two breeding territories. The aim of this study is to describe diet composition and spatio-temporal patterns of predation by peregrines on large gulls, and to determine if diet specialization occurs amongst these breeding pairs. 


\section{Material and methods}

S t u d y a r e a

Lundy $\left(51^{\circ} 11^{\prime} \mathrm{N}, 04^{\circ} 40^{\prime} \mathrm{W}\right)$ is situated between the Bristol Channel and the Atlantic Ocean, approximately 18 $\mathrm{km} \mathrm{NW}$ of the United Kingdom (UK) mainland in the county of Devon. It is approximately five $\mathrm{km}$ long by one $\mathrm{km}$ at its widest point, with approximately $13 \mathrm{~km}$ of coastline consisting mainly of granite sea cliffs, with shale and basalt cliffs in the south-east quarter. Altitude on the island plateau ranges from $80-143 \mathrm{~m}$ a.s.1., covering an area of approximately 445 ha. The island has a variety of habitats (including sea cliffs, boulder beaches, rocky platforms, deciduous shrub woodlands and freshwater ponds), however more than two-thirds of the plateau is unimproved grassland, moorland and maritime heath, dominated by heather (Calluna vulgaris). The southern third of the island supports a small tourist and farming community where the greater land area is semi-improved and improved grassland.

\section{D a t a c o ll e c t i o $\mathrm{n}$}

Samples were collected monthly between April and September 2014-2016 from five nesting pairs. Food items were recorded indirectly from prey remains (including feathers, bones and carcasses) left after feeding, following a pre-determined circuit of the island, in line with Velarde (1993). Systematic searches were also conducted within territories, checking regular plucking areas along sea cliffs and slopes adjacent to nest cliffs. Determining peregrine food habits from feeding remains is an established indirect method of assessing raptor diet (Ratcliffe 1993, Marti et al. 2007). Prey remains were assigned to a territory if located within a $400 \mathrm{~m}$ radius of the nest cliff. This distance was set as the minimum cross-over radius between territories to prevent recording outside of a known territory. The territories were defined on cardinal points of the compass as: L1/NE (North-East); L2/E (East); L3/S (South); L4/SW (South-West); L5/W (West). Any remains found outside the $400 \mathrm{~m}$ radius from nest cliffs were assigned to the random category.

Prey remains were removed for identification and the location recorded with a handheld Global Positioning System (GPS) device to a ten-figure Ordnance Survey grid reference to prevent double recording on a subsequent visit. Remains observed in inaccessible feeding areas were recorded for later analysis using a Digital Single Lens Reflex (DSLR) camera fitted with a telephoto lens and the location recorded indirectly using
GPS computer software (Garmin ${ }^{\circledR}$ BaseCamp ${ }^{\mathrm{TM}}$, Olathe, Kansas, USA). Identification was based on Brown et al. (2003) and on personal experience from previous raptor dietary studies (Sutton 2015a, 2016). Where identification of a prey species was unknown, samples were sent to E. Drewitt (Drewitt \& Dixon 2008). Avian prey remains from peregrines are readily identified; on carcasses the breast is ruptured and totally consumed and the breastbone often has distinct notches made from the peregrine's beak when feeding (Bang \& Dahlstrom 2011). Plucked feathers will often be found concentrated in a distinct pile surrounding the carcass, indicating a kill.

\section{Statistica 1 a na 1 y s is}

Large gulls were divided into four prey groups (adult herring gulls; immature lesser black-backed gulls; immature herring gulls; unidentified immature gulls). Variation in total gull prey frequency between sites, months and years was compared using Fisher's Exact test. Dietary breadth $(B)$ was calculated on the sum total of all prey items using the formula of Levins (Krebs 1999):

$B=1 / \sum p^{2}$

where $p_{\mathrm{i}}$, represents the proportion of the diet contributed by the ith taxon. Values for this index range from 1 to $n$, with a lower number indicating a narrower dietary breadth. Linear regression was used to test the relationship between the percentage of gulls in the diet with total dietary breadth. Statistical calculations were conducted in R (version 3.3.1, R Core Team 2016).

\section{Results}

A total of 78 large gull prey samples were collected and recorded as a specific species or genus and whether adult or immature (Tab. 1). Large gulls comprised $18.44 \%$ by frequency of total prey recorded $(n=423)$ and $30.81 \%$ by biomass. Within the large gulls, herring gulls were the most common prey, with immatures most frequent $(67.95 \%)$ compared to adults $(19.23 \%)$. Overall, most gulls predated were immatures $(80.77 \%)$.

I $\mathrm{ntr}$ a - pa i r variation

The majority of gull predation was on the west side of the island in territories L4/SW and L5/W, within foraging range of the main gull colonies on Lundy. However, the pair in territory L5/W showed possible 
Tab. 1. Prey frequency and biomass of large gulls (Laridae) predated by peregrine falcons (Falco peregrinus) breeding on Lundy Island. Unit mass taken from BTO (2016); all measurements of mass in g.

Tab. 1. Frekvencia koristi a biomasa vel'kých čajok (Laridae) predovaných sokolmi st’ahovavými (Falco peregrinus) hniezdiacimi na ostrove Lundy. Jednotková hmotnost' prebratá z BTO (2016): hmotnost' je vyjadrená v gramoch.

\begin{tabular}{llcc}
\hline $\begin{array}{l}\text { species / } \\
\text { druh }\end{array}$ & $\begin{array}{l}\text { unit mass / } \\
\text { jednotková hmotnost' }\end{array}$ & $\begin{array}{l}\text { frequency (\%) / } \\
\text { frekvencia (\%) }\end{array}$ & $\begin{array}{l}\text { total biomass (\%) / } \\
\text { celková biomasa (\%) }\end{array}$ \\
\hline $\begin{array}{l}\text { Larus argentatus, adult } \\
\text { Immatures / mladé: }\end{array}$ & 971 & $15(19.23)$ & $14,565(19.58)$ \\
Larus fuscus & 785 & $3(3.85)$ & $2,355(3.17)$ \\
L. argentatus & 957 & $53(67.95)$ & $50,721(68.18)$ \\
unidentified gull / neurčená čajka & 964 & $7(8.97)$ & $6,748(9.07)$ \\
\hline$\sum$ & & $78(100.00)$ & $74,389(100.00)$
\end{tabular}

diet specialization in large gulls, most focused during April and May. The resident pair in territory L5/W predated large gulls most frequently $(56.41 \%)$, followed by the pair in territory L4/SW $(24.35 \%)$, though the difference in frequency of gull predation between territories was not statistically significant $(\mathrm{P}=0.119)$ (Fig. 1). Temporal frequency of predation differed significantly between months $(\mathrm{P}=0.014)$. Most gulls were taken in April (37.17\%), followed by May (19.23\%), with a smaller peak in predation of immature herring gulls focused in August and September (Fig. 2). Frequency of predation between years showed a regular pattern of annual predation with no significant difference $(\mathrm{P}=$ 0.598) (Fig. 3). Comparing the percentage of gulls in total diet with dietary breadth showed a weak inverse,

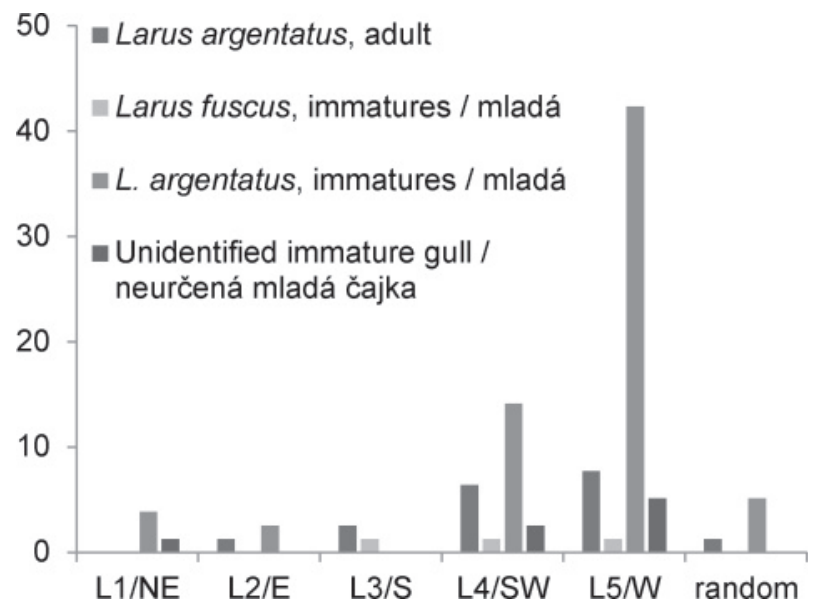

Fig. 1. Spatial variance in frequency (\%) of large gulls predated by peregrine falcons (Falco peregrinus) breeding on Lundy Island (Fishers Exact, $\mathrm{P}=0.119)$. L1/NE-L5/W = nest territories.

Obr. 1. Priestorová variabilita frekvencie (\%) predovania vel'kých čajok sokolmi st'ahovavými (Falco peregrinus) hniezdnacimi na ostrove Lundy (Fishers Exact, $\mathrm{P}=0,119$ ). $\mathrm{L} 1 / \mathrm{NE}-\mathrm{L} 5 / \mathrm{W}=$ hniezdne teritóriá; random = náhodné. but not significant relationship. Up to $21 \%$ of the variance in dietary breadth is explained by the percentage of large gulls in the diet $\left(\mathrm{F}_{1,3}=0.798, \mathrm{P}=0.438, \mathrm{R}^{2}=0.21\right)$ (Fig. 4).

\section{Discussion}

The results given here confirm that large gulls are an important food resource for specific peregrines breeding on Lundy. There was strong variation in seasonal and geographical frequency of predation and the age of individuals taken. Most large gulls were predated in two nest territories on the west side of the island during April and May, the majority of which were immatures. The trend of regular predation by peregrines on large prey has important implications for understanding IDS

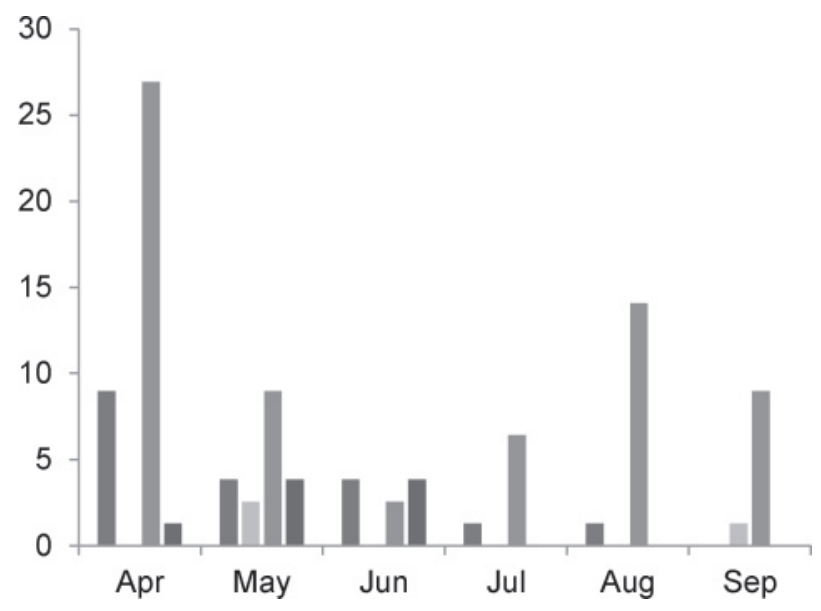

Fig. 2. Temporal variance by month in frequency (\%) of large gulls predated by peregrine falcons (Falco peregrinus) breeding on Lundy Island (Fishers Exact, $\mathrm{P}=0.014)$. See Fig. 1 for legend.

Obr. 2. Mesačná časová variabilita frekvencie (\%) predovania vel'kých čajok sokolmi st’ahovavými (Falco peregrinus) hniezdnacimi na ostrove Lundy (Fishers Exact, $P=0,014$ ). Legenda je na obr. 1. 
and its effect on population and community structure. Although IDS has been described in several peregrine populations from North and South America (Beebe 1960, Verlade 1993, Castellanos et al. 2006, Garcia et al. 2014), quantitative data on this particular aspect of behaviour is sparse from much of the peregrine's global range. Herring gulls and lesser black-backed gulls have been recorded as prey in coastal south Devon, UK $(5.33 \%$ and $3.73 \%$ by biomass respectively), and though important in terms of biomass they were taken infrequently (Sutton 2015a). Ratcliffe (1993) documents both species as infrequent prey from two studies in coastal areas of Highland Scotland, but due to their high unit mass they constituted an important element of total prey biomass.

Data from coastal Argentina show the main prey species were cayenne terns (Thalasseus sandvicensis eurygnathus); (mean mass $=\sim 250 \mathrm{~g}$ ), but despite being more than five times more numerous, adult kelp gulls (Larus dominicanus); $(\sim 1,000 \mathrm{~g})$ did not feature in the diet of the peregrines studied (Garcia et al. 2014). A similar pattern was observed in coastal Washington State, USA, where the resident peregrines largely ignored the locally abundant adult glaucous-winged gull (Larus glaucescens); (1130 g) and common murre (Uria

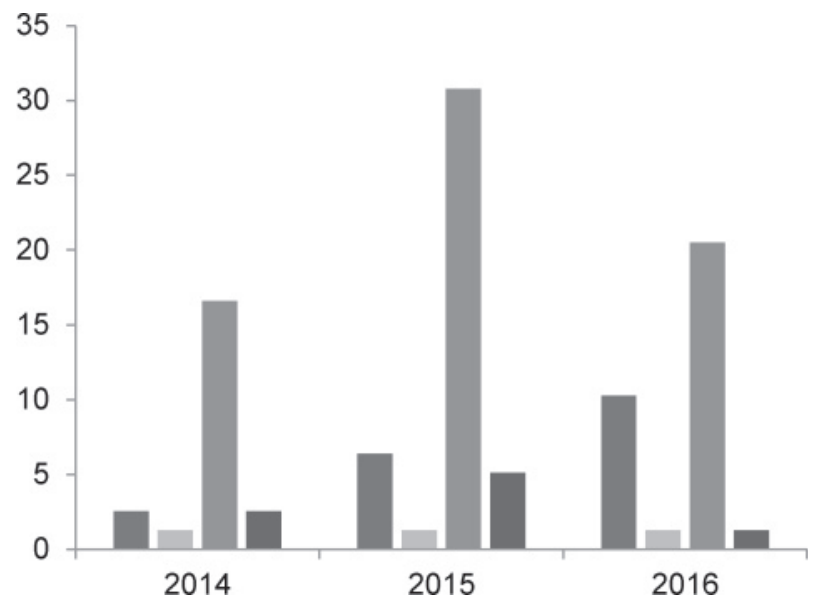

Fig. 3. Temporal variance by year in frequency (\%) of large gulls predated by peregrine falcons (Falco peregrinus) breeding on Lundy Island (Fishers Exact, $P=0.598$ ). See Fig. 1 for legend.

Obr. 3. Ročná časová variabilita frekvencie (\%) predovania vel'kých čajok sokolmi st’ahovavými (Falco peregrinus) hniezdnacimi na ostrove Lundy (Fishers Exact, $P=0,598)$. Legenda je na obr. 1. aalge); (1,010 g) as prey, and focused on smaller prey species: cassin's (Ptychoramphus aleuticus); (170 g) and rhinoceros auklet (Cerorhinca monocerata); (540 g) (Paine et al. 1990). However, immature glaucouswinged gulls were predated at a low level, similar to the results given here, suggesting that this behaviour focuses on the vulnerability of younger individuals that do not have the experience or strength to evade capture by peregrines.

Large gulls were mainly predated on Lundy by two breeding pairs of peregrines holding territories on the west side of the island. The section of sea cliffs between and within these two territories are where the main breeding colonies of lesser black-backed gulls and herring gulls are located on Lundy (Davis \& Jones 2007). Therefore, this may provide an accessible and abundant food source close to these peregrine territories, enabling efficient capture and processing of prey. The peak of predation in April could be a combination of several factors: an increase in gull numbers after returning from over-wintering elsewhere; increased demand for food from peregrines coming into breeding condition; and lack of other abundant prey to feed on. Whilst there is no evidence given here, an increase in the abundance of other favoured prey species, such as Manx shearwaters,

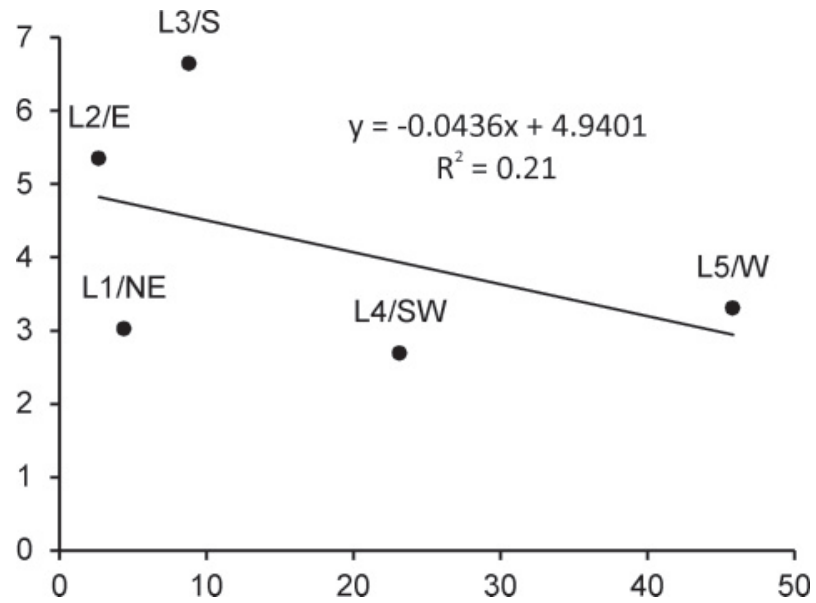

Fig. 4. The relationship between large gulls in total diet (\%) and dietary breadth $(B)$ of peregrine falcons (Falco peregrinus) breeding on Lundy Island. Each black dot represents a resident breeding pair of peregrine falcons with unique identifier code $\left(F_{1,3}=0.798, P=0.438, R^{2}=0.21\right)$.

Obr. 4. Vzt'ah medzi podielom vel'kých čajok $v$ potrave (\%) a potravné spektrum $(B)$ sokolov st'ahovavých (Falco peregrinus) hniezdiacich na ostrove Lundy. Každý bod predstavuje hniezdiaci pár sokolov st’ahovavých s unikátnym identifikačným kódom $\left(F_{1,3}=0,798, P=0,438, R^{2}=0,21\right)$. 
may reduce the level of predation on gulls during June and July, with predation increasing towards August and September possibly in response to the abundance of juvenile gulls post-fledging. The consistent pattern of predation on large gulls over the three-year period suggests this is a regular behaviour and not a response to a sudden increase in food supply or to a decrease in another food resource resulting in prey switching. Further work on prey selection by peregrines on Lundy may show if these patterns exist.

The mechanisms driving IDS in this insular peregrine population are still unclear. Individuals could be restricted by habitat use driven by territoriality in conspecific nesting pairs, therefore limiting access to certain food resources. Patchy habitats could be a key driver by providing different prey types to specific individuals, which then increase their foraging success and handling time by specialization (Sargeant 2007). With such a dense population of peregrines in a small area, intense intra-specific competition between breeding pairs for territorial space and food may be the strongest factor. However, data and observations on home range size and foraging distances would be required to assess how peregrines on islands defend their territories and utilise habitats for these resources. Establishing broadscale patterns of ecological specialization in island populations of peregrines could help inform management of avian community structure on offshore islands. Many of these islands hold globally important populations of seabirds which are the main prey of peregrines. Therefore, considered management of seabird populations could indirectly benefit the predators that utilise them as a food resource.

\section{References}

Araujo MS, Bolnick DI \& Layman CA 2011: The ecological causes of individual specialization. Ecology Letters 14: 948-958.

Bang P \& Dahlstrom P 2011: Animal tracks and signs. OUP Oxford, 264.

Bolnick DI, Svanback R, Fordyce JA, Yang LH, Davis JM, Hulsey CD \& Forister ML 2003: The ecology of individuals: Incidence and implications of individual specialization. The American Naturalist 161: 1-28.

Beebe FL 1960: The marine peregrines of the northwest Pacific coast. The Condor 62: 145-189.

Booker H \& Price D 2014: Manx Shearwater recovery on Lundy: Population and distribution change from 2001 to 2013. Journal of the Lundy Field Society 4: 105-116.
Brown A, Price D, Slader P, Booker H, Lock L \& Deveney D 2011: Seabirds on Lundy: their current status, recent history and prospects for the restoration of a once-important bird area. British Birds 104: 139-158.

Brown R, Ferguson J, Lawrence M \& Lees D 2003: Tracks and signs of the birds of Britain and Europe, 2nd ed. Christopher Helm London, 333.

BTO 2016: http://www.bto.org. Retreived August 25, 2016, from http://www.bto.org/about-birds/birdfacts.

Castellanos A, Arguelles C, Salinas F, Rodriguez A \& Ortega-Rubio A 2006: Diet of breeding peregrine falcons at a coastal lagoon, Baja California Sur, Mexico. Journal of Raptor Research 40(3): 241-244.

Constantini D, Casagrande S, Di Lieto G, Fanfani A \& Dell'Omo G 2005: Consistent differences in feeding habits between neighbouring breeding kestrels. Behaviour 142: 1409-1421. DOI: 10.1163/156853905 774539409 .

Davis TJ \& Jones TA 2007: The birds of Lundy. Devon bird watching and preservation society and Lundy field society, Berrynarbor, Devon, 319.

Dawson RD, Mossop DH \& Boukall B 2011: Prey use and selection in relation to reproduction by peregrine falcons breeding along the Yukon River, Canada. Journal of Raptor Research 45(1): 27-37. DOI: 10.3356/JRR-09-84.1.

Dehnhard N, Eens M, Sturaro N, Lepoint G, Demongin L, Quillfeldt P \& Poisbleau M 2016: Is individual consistency in body mass and reproductive decisions linked to individual specialization in foraging behaviour in a long-lived seabird? Ecology and Evolution 6(13): 4488-4501. DOI: 10.1002/ece3.2213.

Dixon A 2005: The prey of peregrines Falco peregrinus at breeding territories in Northumberland. Transactions of the Natural History Society of Northumbria 64: 111-120.

Drewitt E \& Dixon N 2008: Diet and prey selection of urban-dwelling peregrine falcons in southwest England. British Birds 101: 58-67.

Garcia GO, Susana BoM \& Yorio P 2014: Prey composition of peregrine falcons (Falco peregrinus) preying upon a mixed-species seabird colony in Argentine Patagonia. Ornitologia Neotropical 25: 1-5.

Horswill C, Matthiopoulos J, Ratcliffe N, Green JA, Trathan PN, McGill RAR, Phillips RA \& O'Connell TC 2016: Drivers of intrapopulation variation in resource use in a generalist predator, the macaroni 
penguin. Marine Ecology Progress Series 548: 233-247. DOI: 10.3354/meps11626.

Krebs CJ 1999: Ecological methodology, $2^{\text {nd }}$ ed. Benjamin-Cummings Menlo Park California, 654.

Marti CD, Bechard M \& Jaksic FM 2007: Food habits, 129-151. In: Bird DM, Bildstein KL, Barber DR \& Zimmerman A (eds.) Raptor research and management techniques. Raptor Research Foundation Hancock House Canada, 463.

Navarro-Lopez J, Vergara P \& Fargallo JA 2014: Trophic niche width, offspring condition and immunity in a raptor species. Oecologia 174: 1215-1224. DOI: 10.1007/s00442-013-2855-9.

Nelson RW 1990: Status of the peregrine falcon Falco peregrinus pealei, on Langara Island, Queen Charlotte Islands, British Columbia, 1968-1989. The Canadian Field-Naturalist 104: 193-199.

Nelson RW 2004: The 1995 Peregrine falcon survey on Langara Island, 35-37. In: Banasch U \& Holroyd G (eds.) The 1995 Peregrine falcon survey in Canada. Canadian Wildlife Service Occ. Paper No. 110.

Pagani-Nunez E, Barnett CA, Gu H \& Goodale E 2016: The need for new categorizations of dietary specialism incorporating spatio-temporal availability of individual diet specialization. Journal of Zoology 300 (1): 1-7. DOI: 10.1111/jzo.12364.

Paine RT, Wootton JT \& Boersma PD 1990: Direct and indirect effects of peregrine falcon predation on seabird abundance. The Auk 107: 1-9.

Price D, Slader P \& Booker H 2014: Breeding cliff-nesting seabirds. Lundy Field Society Annual Report 2013 63: 85-92.

Ratcliffe DA 1993: The peregrine falcon. $2^{\text {nd }}$ ed. T \& AD Poyser London, 454.

R Core Team 2016: R: A language and environment for statistical computing. R Foundation for Statistical Computing, Vienna, Austria. https://www.R-project.org/.

Sargeant BL 2007: Individual foraging specialization: niche width versus niche overlap. Oikos 116: 1431-1437. DOI: $10.1111 / \mathrm{j} .0030-1299.2007$. 15833.x.

Schoener TW 1974: Resource partitioning in ecological communities. Science 185: 27-39.
Sutton LJ 2015a: Prey spectrum and foraging behaviour of coastal peregrine falcons Falco peregrinus in South Devon. Devon Birds 68(2): 3-12.

Sutton LJ 2015b: Population status of the peregrine falcon Falco peregrinus on Lundy. Lundy Field Society Annual Report 2014 64: 98-102.

Sutton LJ 2016: Status of the peregrine falcon Falco peregrinus on Lundy: Breeding ecology and prey spectrum. Journal of the Lundy Field Society 5: $75-88$.

Terraube J, Guixe D \& Arroyo B 2014: Diet composition and foraging success in generalist predators: Are specialist individual's better foragers? Basic and Applied Ecology 15: 616-624. DOI: 10.1016/j.baae. 2014.08.008.

Velarde E 1993: Predation of nesting larids by peregrine falcons at Rasa Island, Gulf of California, Mexico. The Condor 95: 706-708.

White CM, Cade TJ \& Enderson JH 2013: Peregrine falcons of the world. Lynx Edicions Barcelona, 379.

Whitfield DP, Reid R, Haworth PF, Madders M, Marquiss M, Tingay R \& Fielding AH 2009: Diet specificity is not associated with increased reproductive performance of golden eagles Aquila chrysaetos in Western Scotland. Ibis 151: 255-264. DOI: 10.1111/j.1474-919X.2009.00924.x.

Wiens JA 1984: Resource systems, populations and communities, 397-436. In: Price PW, Slobodchikoff CN \& Gaud WS (eds.) A new ecology: Novel approaches to interactive systems. John Wiley \& Sons New York, 515.

Wright SJ 1980: Density compensation in island avifaunas. Oecologia 45: 385-389.

Zabala J \& Zuberogoitia I 2014: Individual quality explains variation in reproductive success better than territory quality in a long-lived territorial raptor. PLoS ONE 9(3): e90254. DOI:10.1371/journal. pone. 0090254 .

Zuberogoitia I, Martínez JE, González-Oreja JA, Calvo JF \& Zabala J 2013: The relationship between brood size and prey selection in a peregrine falcon population located in a strategic region on the Western European flyway. Journal of Ornithology 154(1): 73-82. DOI: 10.1007/s10336-012-0872-9. 